\title{
An updated analysis of the surgical and urological complications of 789 living-related donor kidney transplantations: Experience of a single center
}

\author{
Tayfun Oktar, M.D., (ㄱ) Taner Koçak, M.D., (1) Tzevat Tefik, M.D., (1) Selçuk Erdem, M.D.,

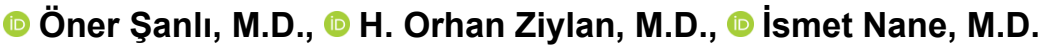

Department of Urology, İstanbul University İstanbul Faculty of Medicine, İstanbul-Turkey

\begin{abstract}
BACKGROUND: This study aims to review retrospectively the surgical and urological complications encountered in 789 cases of living-related donor kidney transplantations (LRDKTs).

METHODS: In this study, the clinical records of 789 LRDKTs, which were performed between 1983 and 2017 , were reviewed retrospectively concerning surgical and urological complications.

RESULTS: Overall, urological and surgical complications were encountered in 87 ( $11.02 \%)$ of the cases. Of the 789 patients, urological complications were detected in 44 of them (5.6\%), including 8 urinary fistula (with I distal ureteral necrosis), 10 ureteric stenosis, I renal calculus, 9 symptomatic vesicoureteral reflux and 16 lymphoceles requiring intervention. As surgical complications ( $\mathrm{n}=43$ ), vascular complications were encountered in 8 cases; there were 5 cases with renal artery stenosis and 3 with renal vein thrombus. Wound infection was detected in 14 patients. Eighteen patients underwent surgical explorations due to perinephric hematoma during the early postoperative period. Renal allograft rupture due to accelerated rejection was developed in 2 cases. A lower segmental arterial injury occurred in I patient during the operation.
\end{abstract}

CONCLUSION: In our series, urological and surgical complications were detected in $11.02 \%$ of the recipients. Although complications still encountered, early identification of these complications with proper management strategies significantly decreases the risk of graft loss.

Keywords: Living donor kidney transplantation; surgical complication; urological complication.

\section{INTRODUCTION}

Living-related donor kidney transplantation (LRDKT) is a significant source of graft, especially in countries that have problems in cadaveric donor source. The surgical and urological complications after kidney transplantation still remain a challenging problem despite refinements and almost standardization of surgical techniques. These complications may lead to devastating consequences, such as graft loss or even death. Thus, early diagnosis and proper management are crucial when dealing with these complications.
The urological complications have been reported to be $2.8 \%$ to $12.5 \%$ in large series. ${ }^{[1-6]}$ In our previous study, which was published in 2004, urological complications were detected in $8 \%$ of the 362 consecutive living-related donor kidney transplantations and surgical complications were encountered in $7.7 \%$ of them. ${ }^{[1]}$ In this present study, we reviewed the urological and surgical complications in 789 consecutive livingrelated kidney transplantations.

\section{MATERIALS AND METHODS}

The clinical records of 789 LRDKTs, which were performed

Cite this article as: Oktar T, Koçak T, Tefik T, Erdem S, Şanlı Ö, Ziylan HO, et al. An updated analysis of the surgical and urological complications of 789 living-related donor kidney transplantations: Experience of a single center. Ulus Travma Acil Cerrahi Derg 2020;26:197-202.

Address for correspondence: Tayfun Oktar, M.D.

İstanbul Üniversitesi İstanbul Tıp Fakültesi, Üroloji Anabilim Dalı, İstanbul, Turkey

Tel: +90 212 - 142000 E-mail: tayfunoktar@hotmail.com

Ulus Travma Acil Cerrahi Derg 2020;26(2):197-202 DOI: 10.14744/tjtes.2019.78805 Submitted: 13.04.2019 Accepted: 07.05.2019 Online: 25.02.2020

Copyright 2020 Turkish Association of Trauma and Emergency Surgery 
between 1983 and 2017, were reviewed retrospectively concerning surgical and urological complications. Of the 789 recipients, 528 were male and $26 \mathrm{I}$ were female. The mean age of the recipients was 30.7 (Range: 4-67) years.

Living donor nephrectomy was performed by the open approach in 694 and by laparoscopy in the last 95 cases. A flank incision with either $11^{\text {th }}$ or $12^{\text {th }}$ rib resecting or intercostal approach was used in open donor nephrectomy. The kidney was then placed in an ice-cold solution and flushed with heparinized Ringer's solution. In the laparoscopic approach, the patients were placed on a lateral position with flexion of the operative table. A I5-mmHg pneumoperitoneum was created and four ports were placed. Extraction was performed via an ipsilateral modified Gibson incision through a specimen bag.

In the surgical technique for adult recipients, as also previously described, the kidney was engrafted extraperitoneally in the contralateral iliac fossa via Gibson incision. The renal vein was anastomosed end-to-side to the external iliac vein with continuous $6 / 0$ monofilament, polypropylene sutures, and the renal artery was anastomosed end-to-end to the internal iliac artery with interrupted sutures or in certain cases end-toside to the external iliac artery, using $6 / 0$ monofilament, nonabsorbable polypropylene sutures. In the presence of multiple renal arteries, reconstruction with side-to-side 'Gun-barrel' anastomosis was performed on the bench. Before all types of vascular anastomosis, vessel lumens were flushed with heparinized saline. Low molecular weight heparins were started on a weight-based dosage postoperatively.

The The Extravesical anterolateral ureteroneocystostomy technique (Lich-Gregoir method) was used for vesicoureteric anastomosis. Before 1997, double-J ureteral catheters were only used in some selected complicated cases; however, after this period, ureteral stents were routinely placed to secure anastomosis and to decrease urological complications. The second generation prophylactic antibiotics were started before the operation and continued until postoperative cultures were known. Indwelling Foley catheters were removed after five to seven days postoperatively in uncomplicated patients.

Informed consents were given to all subjects before the procedures and the protocols conformed to the ethical guidelines of the 1975 Helsinki Declaration. The study protocol was approved by the institutional review board (IRB: 293862).

\section{RESULTS}

Overall, 87 (II.02\%) urological and surgical complications were detected in 789 consecutive living-related kidney transplantations. Urological complications occurred in 44 (5.6\%) transplants, including 10 ureteral stricture, 9 symptomatic vesicoureteral reflux (VUR), 8 urinary fistulas, I renal calculi, and 16 lymphoceles requiring intervention. As surgical complications $(n=43)$, vascular complications were encountered in 8 cases; there were 5 cases with renal artery stenosis and 3 with renal vein thrombus. Eighteen recipients were surgically explored due to perinephric hematoma during the early postoperative period. Renal allograft rupture due to accelerated rejection was observed in 2 patients. A lower segmental arterial injury occurred in I patient during donor nephrectomy. Wound infection was detected in 14 patients.

Stricture at the ureterovesical anastomosis was observed in 10 patients. Initially, the double-J ureteral stent was placed to six cases and percutaneous nephrostomy placement was performed to four patients, in whom double-J stent insertion was unsuccessful. Five of the six ureteric stenoses having ureteric stents were managed by balloon-dilatation of the ureter, without requiring further interventions. One patient was under close follow-up with periodical stent renewal. Of four ureteric stenoses that were initially managed by percutaneous nephrostomy, 3 of them underwent open reconstruction with pyeloureterostomy (I) and ureteroneocystostomy (2) and balloon dilatation with ureteral stent placement was performed to the remaining patient.

Urine leakage at the ureterovesical anastomosis was detected in 8 patients. All of them diagnosed in the early postoperative period, including I case whose leakage developed after surgical exploration for early postoperative hematoma. Open reconstruction was performed to all cases, including the renewal of the anastomosis in 6 cases and pyeloureterostomy to native ureter in 2 patients due to distal ureteric necrosis.

Symptomatic VUR to the transplanted kidney was detected in 9 patients. These patients had recurrent and symptomatic urinary tract infections and were diagnosed during screening VCUG. Endoscopic suburethral injection was performed to 4 patients and 2 cases were treated with surgical reconstruction. The remaining 3 patients with low-grade VUR are under close follow-up, without requiring any surgical intervention.

Postoperative stone formation in the transplanted kidney was observed in I patient, and successfully managed by percutaneous nephrolithotomy due to failure to ESWL. In another case, a lower pole stone in the donor kidney was removed by flexible ureteroscopy on the bench side after donor nephrectomy and transplanted to the recipient without any complication. Lymphoceles requiring interventions were observed in 16 cases. Percutaneous drainage was performed in 10 cases. In the remaining 6 lymphoceles, intraperitoneal drainage with fenestration was required, including 4 with open surgery and 2 with a laparoscopic approach. Renal vein thrombosis developed in 3 recipients. Allograft nephrectomy was performed in 2 cases. In I patient, early exploration and thrombectomy, with subsequent explanation were performed and the kidney was successfully placed to the contralateral side, with an uneventful postoperative period. Renal arterial stenosis was observed in 5 cases. Percutaneous angioplasty was performed 
Table I. Comparison of the urological complications between 1983-2002 and 2002-2017

\begin{tabular}{lccc}
\hline Urological complications & $\begin{array}{c}1983-2002 \\
(\mathbf{n = 3 6 2 )}\end{array}$ & $\begin{array}{c}\mathbf{2 0 0 2 - 2 0 1 7} \\
(\mathbf{n = 4 2 7})\end{array}$ & $\begin{array}{c}\text { Overall } \\
(\mathbf{n}=\mathbf{7 8 9})\end{array}$ \\
\hline Ureteric obstruction & 2 & 8 & 10 \\
Urinary leakage & 5 & 3 & 8 \\
VUR (Vesico-ureteral reflux) & 8 & 1 & 9 \\
Calculi & 1 & 0 & 1 \\
Lymphocele & 13 & 3 & 16 \\
Overall & $29(8.01 \%)$ & $15(3.5 \%)$ & $44(5.6 \%)$ \\
\hline
\end{tabular}

Table 2. Comparison of the surgical complications between 1983-2002 and 2002-2017

\begin{tabular}{lccc}
\hline Surgical complications & $\begin{array}{c}1 \text { 983-2002 } \\
(\mathbf{n}=\mathbf{3 6 2})\end{array}$ & $\begin{array}{c}\mathbf{2 0 0 2 - 2 0 1 7} \\
(\mathbf{n}=\mathbf{4 2 7})\end{array}$ & $\begin{array}{c}\text { Overall } \\
(\mathbf{n}=\mathbf{7 8 9})\end{array}$ \\
\hline Renal artery stenosis & 5 & 0 & 5 \\
Renal vein thrombosis & 0 & 3 & 3 \\
Perinephric hematoma & 14 & 4 & 18 \\
Renal allograft rupture & 2 & 0 & 2 \\
Wound infection & 6 & 8 & 14 \\
Lower segmental arterial injury & 1 & 0 & 1 \\
Overall & $28(7.7 \%)$ & $15(3.5 \%)$ & $43(5.44 \%)$ \\
\hline
\end{tabular}

to 3 patients and in the remaining 2 recipients, stenosis was diagnosed to be less than $50 \%$ of the artery with no renal functional impairment, and no intervention was required.

In one patient, the lower segmental artery was unintentionally injured during donor nephrectomy, reconstructed intraoperatively and anastomosis was performed. However, on a postoperative day 14, lower pole resection was required due to poor circulation. The postoperative period was uneventful. The comparison of urological and surgical complications between two periods of time (1983-2002 vs 2002-2017) is given in Table I and Table 2, respectively.

\section{DISCUSSION}

Kidney transplantation is the ideal management of the patients with end-stage renal disease. However, in some countries, there may be problems to find cadaveric donor candidates due to social and religious factors and in these situations, living-related kidney donors become a viable option for kidney transplantation. However, urological and surgical complications are still a major source of morbidity and may lead to graft and even patient loss. In our series, overall, urological and surgical complications were detected in $11.02 \%$ of the cases.

Urological complications have been reported to be between $2.8 \%$ and $12.5 \%$ in some large series. ${ }^{[1-6]}$ Bessede et al. ${ }^{[6]}$ have detected urological complications in $11.2 \%$ of 3129 kidney transplants, which were mainly recovered from cadaveric donors $(92.5 \%)$. The different rates of complications in the literature could be partially explained by the inclusion of all types of complications, such as stricture, obstruction, reflux, lymphoceles and stones, in these series. In our series, urological complications were observed in $5.6 \%$ of the recipients. Urological complications are mainly due to technical factors. Preservation of periureteric fatty tissue to maintain ureteral blood supply is a crucial factor to decrease ureteral ischemia related complications. Also, to shorten the ureter to a minimum length necessary to achieve a tension-free anastomosis without kinking and with a lesser risk of ischemic injury is an important surgical principle for the reduction of these complications. ${ }^{[6,7]}$ The type of ureteral reimplantation is another significant factor affecting complication rates. In our series, extravesical ureteroneocystostomy (Lich-Gregoir) was performed in all cases. This technique has several advantages, including decreased bladder bleeding, the use of a shorter segment of the ureter and decreased operative time. ${ }^{[8]}$

Ureteral stricture and urinary leakage are the most commonly reported urological complications. In our series, ureteral stricture was observed in 10 (1.26\%) cases. Ureteral strictures are mainly due to ureteral ischemia resulting in fibrosis, immunological factors, infections, extrinsic compression by hematoma or lymphocele, and acute or chronic rejec- 
tion episodes. ${ }^{[9-11]}$ Ureteral stenting after balloon dilatation or surgical reconstruction is the treatment options for the management of these strictures. Although reimplantation of the ureter is the treatment of choice for the ureterovesical complications, the use of native ureter, when available, as pyeloureterostomy or ureteroureterostomy, is a valuable management alternative, with good long-term results reported in the literature. ${ }^{[12,13]}$ In our series, although balloon dilatation and ureteral stenting were successful in five cases, open reconstruction with pyeloureterostomy (2) and ureteroneocystostomy (I) was required in three patients, without any further complications.

The urinary leakage was reported to be $1.2 \%$ to $13 \%$ in the literature. ${ }^{[4,6,14]}$ The early postoperative leakage is generally due to anastomosis dehiscence, and ureteral ischemia with necrosis is the most common cause of the late presented cases. In our series, urinary leakage was observed in 8 ( $1.01 \%)$ patients, all requiring open reconstruction. The use of ureteral stents in renal transplantation remains a controversial topic and has been debated extensively in the literature. The rationale for the routine use of the stents is to decrease the complications related to the ureterovesical anastomosis, as used in other reconstructive urological operations. In a meta-analysis, including five randomized studies and 44 case series, it was reported that stented extravesical ureteroneocystostomy had a significantly lower urologic complication rate than those with non-stented anastomosis which was $1.5 \%$ in stented versus $9 \%$ in non-stented subjects in controlled trials group. ${ }^{[15]}$ In a more recent meta-analysis, Wilson et al. ${ }^{[16]}$ reported that the incidence of major urological complications was significantly reduced by prophylactic stenting. In our series, since 1997, we have routinely used ureteral stents in renal recipients.

The incidence of post-transplant VUR has been reported to be between $1 \%$ to $86 \%$ in the literature. ${ }^{[17-20]}$ This wide range of VUR detection can be explained by the differences in the indications and timing of imaging and surgical techniques used for implantation. The clinical consequences of post-transplant VUR and its impact on graft function is also a matter of debate. In a study with 1008 adult renal transplant recipients of whom a I-week post-transplant voiding cystourethrogram was available, VUR was detected 106 (10.5\%) graft recipients. ${ }^{[20]}$ Oneand 5-year graft survival in patients with VUR was $85.8 \%$ and $82.1 \%$ compared to $87.3 \%$ and $83.0 \%$ in patients without VUR and no significant difference was observed between the two groups. However, in case of recurrent, symptomatic infections, interventions for correction of post-transplant reflux are indicated, which includes endoscopic injection treatment and open surgical reconstruction. In our series, endoscopic suburethral injection or surgical reconstruction was performed to 6 patients. The remaining 3 patients with low-grade VUR are under close follow-up, without requiring further treatment.

Lymphoceles requiring interventions were observed in 16 cases. Careful ligation of lymphatic vessels originating from the recipient's peri-iliac network and the hilum of the donor kidney significantly reduces the formation of lymphoceles. Percutaneous drainage was performed in 10 cases. In the remaining 6 lymphoceles, intraperitoneal drainage was required, including 4 with open surgery and 2 with the laparoscopic approach. The post-transplant incidence of urolithiasis is reported to be between 0.2 and $1.8 \%$ in the literature. ${ }^{[9,21,22]}$ The stone can be formed de novo or can be donor-related. Although it is a rare event, urinary obstruction, sepsis and loss allograft function are the potentially serious complications requiring proper diagnosis and management. In our series, the post-transplant stone was observed in one patient, and successfully managed by percutaneous nephrolithotomy due to failure to ESWL. In another case, a lower pole stone in a donor kidney was successfully managed by flexible ureteroscopy on the bench side and the stone-free graft was transplanted to the recipient, which might be a useful approach to donor kidneys with stones, especially in case of shortage of grafts. Renal artery stenosis after transplantation has been reported to be $1 \%$ to $23 \%$ in the literature, although the true incidence may vary depending on the routine screening and the method of diagnosis of the stenosis. ${ }^{[23,24]}$ Graft dysfunction and hypertension are the most common indications for intervention. Treatment options include medical management, percutaneous transluminal angioplasty, stent placement and surgical reconstruction. Percutaneous transluminal angioplasty is the most commonly used treatment modality. In our series, post-transplant renal artery stenosis was detected in 5 cases, and percutaneous angioplasty was required in 3 of them. In the remaining two patients, stenosis was diagnosed to be less than $50 \%$ of the artery with no renal functional impairment and no intervention was required.

Renal vein thrombosis is a serious vascular complication, usually occurring in the early postoperative period and is one of the main causes of early graft dysfunction and loss. The reported incidence ranges from $0.1 \%$ to $4.2 \% .^{[25-27]}$ The etiologic factors are technical issues, including anastomotic stenosis and kinking of the vein, compression of renal vein by hematomas or lymphoceles, atherosclerotic vessels in recipients and immunosuppression. Renal vein thrombosis developed in three of our patients. Allograft nephrectomy was performed to two of them. In one patient, early exploration and thrombectomy, with subsequent explanation were performed and the kidney was successfully placed to the contralateral side, with an uneventful postoperative period. The use of kidneys from living donors with renal artery aneurysms (RAA) is an option for selected cases having problems in finding donor kidney source. In our series, a donor kidney from a 64 years old male with a $1.5 \mathrm{~cm}$ saccular RAA at the branch of the left renal artery was reconstructed on the bench, using an arterial wall patch and transplanted successfully, without any postoperative complication. Overall, in our series of 789 LRDKTs, the urological and surgical complications tend to decrease with time. The use of routine ureteral stents for 
ureterovesical anastomosis and to limit the dissection of external iliac veins for the reduction of lymphoceles is important technical factors for the prevention of these complications. For vascular complications, proper management strategies, including early intervention, can prevent graft loss in selected cases. In case of graft shortage, surgical reconstruction and bench interventions may expand the donor selection, as in our donor case with renal arterial patch and the other donor kidney with lower pole stone. In conclusion, modifications and standardization of surgical techniques of kidney transplantation, as well as early identification of complications, significantly decrease the risk of graft loss.

Ethics Committee Approval: Approved by the local ethics committee.

\section{Peer-review: Internally peer-reviewed.}

Authorship Contributions: Concept: T.O., T.K.; Design: T.O., T.K.; Supervision: T.O., T.K., H.O.Z, I.N.; Materials: T.O., T.K., T.T., S.E., Ö.Ş., H.O.Z., I.N.; Data: T.O., T.K., T.T., S.E., Ö.Ş., H.O.Z., I.N.; Analysis: T.O., T.K.; Literature search: T.O., T.K., T.T., S.E.; Writing: T.O., T.K.; Critical revision: T.O., T.K., Ö.Ş., H.O.Z., I.N.

\section{Conflict of Interest: None declared.}

Financial Disclosure: The authors declared that this study has received no financial support.

\section{REFERENCES}

1. Koçak T, Nane I, Ander H, Ziylan O, Oktar T, Ozsoy C. Urological and surgical complications in 362 consecutive living related donor kidney transplantations. Urol Int 2004;72:252-6. [CrossRef]

2. Ohl DA, Konnak JW, Campbell DA, Dafoe DC, Merion RM, Turcotte JG. Extravesical ureteroneocystostomy in renal transplantation. J Urol 1988;139:499-502. [CrossRef]

3. Mundy AR, Podesta ML, Bewick M, Rudge CJ, Ellis FG. The urological complications of 1000 renal transplants. Br J Urol 1981;53:397-402.

4. Streeter EH, Little DM, Cranston DW, Morris PJ. The urological complications of renal transplantation: a series of 1535 patients. BJU Int 2002;90:627-34. [CrossRef]

5. Mäkisalo H, Eklund B, Salmela K, Isoniemi H, Kyllönen L, Höckerstedt $\mathrm{K}$, et al. Urological complications after 2084 consecutive kidney transplantations. Transplant Proc 1997;29:152-3. [CrossRef]

6. Bessede T, Hammoudi Y, Bedretdinova D, Parier B, Francois H, Durrbach A, et al. Preoperative Risk Factors Associated With Urinary Complications After Kidney Transplantation. Transplant Proc 2017;49:2018-24.

7. Raman A, Lam S, Vasilaras A, Joseph D, Wong J, Sved P, et al. Influence of ureteric anastomosis technique on urological complications after kidney transplantation. Transplant Proc 2013;45:1622-4. [CrossRef]

8. Butterworth PC, Horsburgh T, Veitch PS, Bell PR, Nicholson ML. Ureterovesical anastomosis in renal transplants: fewer complications with the extravesical technique. Transplant Proc 1997;29:151. [CrossRef]
9. Krajewski W, Dembowski J, Kołodziej A, Małkiewicz B, Tupikowski K, Matuszewski M, et al. Urological complications after renal transplantation - a single centre experience. Cent European J Urol 2016;69:306-11.

10. Shoskes DA, Hanbury D, Cranston D, Morris PJ. Urological complications in 1,000 consecutive renal transplant recipients. J Urol 1995;153:18-21. [CrossRef]

11. Palazzetti A, Oderda M, Dalmasso E, Falcone M, Bosio A, Sedigh O, et al. Urological consequences following renal transplantation: a review of the literature. Urologia 2015;82:211-8. [CrossRef]

12. Salomon L, Saporta F, Amsellem D, Hozneck A, Colombel M, Patard JJ, et al. Results of pyeloureterostomy after ureterovesical anastomosis complications in renal transplantation. Urology 1999;53:908-12. [CrossRef]

13. Schult M, Küster J, Kliem V, Brunkhorst R, Nashan B, Oldhafer KJ, et al. Native pyeloureterostomy after kidney transplantation: experience in 48 cases. Transpl Int 2000;13:340-3. [CrossRef]

14. Dörsam J, Knopp MV, Carl S, Oesingmann N, Schad L, Brkovic D, et al. Ureteral complications after kidney transplantation--evaluation with functional magnetic resonance urography. Transplant Proc 1997;29:132-5. [CrossRef]

15. Mangus RS, Haag BW. Stented versus nonstented extravesical ureteroneocystostomy in renal transplantation: a metaanalysis. Am J Transplant 2004;4:1889-96. [CrossRef]

16. Wilson $\mathrm{CH}$, Rix DA, Manas DM. Routine intraoperative ureteric stenting for kidney transplant recipients. Cochrane Database Syst Rev 2013;:CD004925. [CrossRef]

17. Kayler L, Kang D, Molmenti E, Howard R. Kidney transplant ureteroneocystostomy techniques and complications: review of the literature. Transplant Proc 2010;42:1413-20. [CrossRef]

18. Coosemans W, Rega F, Roels L, Peeters J, Donck J, Vanwalleghem J, et al. Impact of early vesico ureteral reflux on the transplanted kidney. Transplant Proc 1999;31:362-4. [CrossRef]

19. Mastrosimone S, Pignata G, Maresca MC, Calconi G, Rabassini A, Butini R, et al. Clinical significance of vesicoureteral reflux after kidney transplantation. Clin Nephrol 1993;40:38-45.

20. Molenaar NM, Minnee RC, Bemelman FJ, Idu MM. Vesicoureteral Reflux in Kidney Transplantation. Prog Transplant 2017;27:196-9. [CrossRef]

21. Mamarelis G, Vernadakis S, Moris D, Altanis N, Perdikouli M, Stravodimos $\mathrm{K}$, et al. Lithiasis of the renal allograft, a rare urological complication following renal transplantation: a single-center experience of 2,045 renal transplantations. Transplant Proc 2014;46:3203-5. [CrossRef]

22. Saxena S, Sadideen H, Goldsmith D. Treating stones in transplanted kidneys. Minerva Med 2013;104:31-40.

23. Chen LX, De Mattos A, Bang H, Vu CT, Gandhi M, Alnimri M, et al. Angioplasty vs stent in the treatment of transplant renal artery stenosis. Clin Transplant 2018;32:e13217. [CrossRef]

24. Bruno S, Remuzzi G, Ruggenenti P. Transplant renal artery stenosis. J Am Soc Nephrol 2004;15:134-41. [CrossRef]

25. El Zorkany K, Bridson JM, Sharma A, Halawa A. Transplant Renal Vein Thrombosis. Exp Clin Transplant 2017;15:123-9.

26. Bakir N, Sluiter WJ, Ploeg RJ, van Son WJ, Tegzess AM. Primary renal graft thrombosis. Nephrol Dial Transplant 1996;11:140-7. [CrossRef]

27. Fathi T, Samhan M, Gawish A, Donia F, Al-Mousawi M. Renal allograft venous thrombosis is salvageable. Transplant Proc 2007;39:1120-1. 
ORİJINAL ÇALIŞMA - ÖZET

\section{Canlı donörden böbrek transplantasyonunda cerrahi ve ürolojik komplikasyonların} 789 olguda güncellenmiş analizi: Tek bir merkez tecrübesi

\section{Dr. Tayfun Oktar, Dr. Taner Koçak, Dr. Tzevat Tefik, Dr. Selçuk Erdem,}

Dr. Öner Şanlı, Dr. H. Orhan Ziylan, Dr. İsmet Nane

İstanbul Üniversitesi İstanbul Tıp Fakültesi, Üroloji Anabilim Dalı, İstanbul

AMAÇ: Bu çalışmanın amacı, 789 canlı donörden böbrek transplantasyon (CDBT) olgusunda cerrahi ve ürolojik komplikasyonların geriye dönük olarak değerlendirilmesidir.

GEREÇ VE YÖNTEM: Anabilim dalımızda 1983 ve 2017 yılları arasında yapılan 789 CDBT olgusunun klinik bilgileri cerrahi ve ürolojik komplikasyonlar bakımından geriye dönük olarak değerlendirildi.

BULGULAR: Ürolojik ve cerrahi komplikasyonlar 87 (\%।I.02) olguda tespit edildi. Olguların 44'ünde (\%5.6) görülen ürolojik komplikasyonlar sekiz olguda üriner fistül ( I’i distal üreter nekrozu ile birlikte), I0 olguda üreter stenozu, I olguda renal kalkül, 9 olguda semptomatik vezikoüreteral reflü ve 16 hastada girişim gerektiren lenfosel idi. Cerrahi komplikasyonlar ise $(n=43), 5^{\prime} i$ renal arter stenozu ve 3 'ü renal ven trombozu olmak üzere toplam 8 olguda vasküler komplikasyon, 14 yara yeri enfeksiyonu, 18 erken ameliyat sonrası cerrahi eksplorasyon gerektiren perinefrik hematom, 2 akselere rejeksiyon nedeniyle renal allograft rüptürü ve bir ameliyat sırasında alt segmental arter hasarı idi.

TARTIŞMA: Çalışmamızda ürolojik ve cerrahi komplikasyonlar alıııların \% II.2'sinde saptanmıştır. Bu komplikasyonların erken tanınması ve uygun stratejilerle yönetilmesi greft kaybı riskini anlamlı ölçüde azaltmaktadır.

Anahtar sözcükler: Canlı donörden böbrek transplantasyonu; cerrahi komplikasyon; ürolojik komplikasyon.

Ulus Travma Acil Cerrahi Derg 2020;26(2):197-202 doi: 10.14744/tjtes.2019.78805 